American Journal of Agricultural and Biological Sciences 5 (2): 189-193, 2010

ISSN 1557-4989

(C) 2010 Science Publications

\title{
Evaluation the Effects of Biological Fertilizer on Physiological Characteristic and Yield and its Components of Corn (Zea mays L.) Under Drought Stress
}

\author{
${ }^{1}$ Barmak Jafari Haghighi, ${ }^{1}$ Zeynab Yarmahmodi and ${ }^{2}$ Omid Alizadeh \\ ${ }^{1}$ Department of Agronomy, Islamic Azad University, Arsanjan Branch, Iran \\ ${ }^{2}$ Department of Agronomy, Islamic Azad University, Firozabad Branch, Iran
}

\begin{abstract}
Problem statement: This experiment was carried out for study the effects of chemical and biological fertilizers and interaction between them on some physiological characteristic and yield and its components of seed corn in two different irrigation. Approach: The experiment was conducted in a split plot factorial with completely randomized block design using four replications. Sub plots consisted of combined application levels $\mathrm{N}$-fertilizer with two level $\left(0\right.$ and $\left.300 \mathrm{~kg} \cdot \mathrm{ha}^{-1}\right)$ Urea and two level of biological fertilizer $\left(0\right.$ and $\left.4 \mathrm{~L} \cdot \mathrm{ha}^{-1}\right)$ in four stage that was from 4th leaf appearance until milk stage. Biological fertilizer was combined of Kadostim, Phosphotern, Aminolephorte and Hyomiphorte. Main plots consisted of two period of irrigation ( 8 and 12 days). Results: The results showed that highest grain yield was in conditional application at integrated treatment $300 \mathrm{~kg} . \mathrm{ha}^{-1}$ Urea fertilizer and 4 L.ha ${ }^{-1}$ biological fertilizer $\left(12.5\right.$ ton.ha $\left.{ }^{-1}\right)$ that with compared to control treatment showed increase $257 \%$. In this treatment decrease irrigation (12 days period of irrigation) from pollination stage to seed maturity, decreased $8.9 \%$ in yield. The highest kernel number per ear and highest 1000 kernel weight was in integrated fertilizer treatment but in 8 days period of irrigation was not significant difference between integrated treatment and chemical treatment for 1000 kernel weight. The integrated treatment in 8 days period of irrigation showed the highest CGR, NAR and LAI $\left(14.2 \mathrm{~g} . \mathrm{m}^{-2}\right.$.day ${ }^{-1}$, 2.9 g. $\mathrm{LA}_{\mathrm{LA}}{ }^{-2}$.day ${ }^{-1}$ and 5.1) respectively. And decrease 12 days period of irrigation had little effect on CGR and NAR but application of chemical fertilizer after decrease irrigation CGR had much reduce trend to compared integrated treatment. Conclusion: In conclusion for reach to high yield in corn biological fertilizer can not sufficient but integrated application of fertilizers (biological and chemical fertilizers) became causes significant increase in yield.
\end{abstract}

Key words: Fertilizer, yield and yield components, CGR, NAR, LAI

\section{INTRODUCTION}

Organic agriculture is one of the ways that can produce high quality crops (Higa, 1994). Most of the studies, in this area have been shown that consecutive uses of chemical fertilizer causes soil erosion and lower crops quality (Kumar and Kumar, 2004). Because of high environmentally adaptation and reducing the need of fertilizer consumption biostimulators, not only decrease the negative effects of chemical fertilizer but also increase yield with regarding to sustainable agriculture. In addition, the use of biostimulators in condition of environmental stress can decrease effects of stress and enhance soil water holding capacity, root growth and yield ( $\mathrm{Li}$ and $\mathrm{Ni}, 1996$; Fisher and Wilson, 1975). In addition to soil application, nutritional elements can be used as foliar application. Nutritional spray on plants can decrease the delay between absorption and consumption of elements by plant, that is very important for fast growth stage of plant (Taiz and Zeiger, 2002). Obviously, combined application of organic fertilizer and urea fertilizer or combination urea fertilizer and polyamines significantly increased yield, vegetative growth and chlorophyll index (Oad et al., 2004; Zeid, 2008). Follet et al. (1981) reported that chlorophyll correlation is related to the amount of nutrients absorbed by the plant from the soil (6). Sivasubramaniawn (1992) related the drought resistance of plants to the chlorophyll stability index that has been employed to determine the thermostability of chlorophyll (14). This study was therefore designed to investigate the effects of applications of biological

Corresponding Author: Omid Alizadeh, Department of Agronomy, Islamic Azad University, Firozabad Branch, Iran Tel: +98-7126236742 
fertilizer and chemical fertilizer on leaf area index, Crop Growth Rate (CGR), Net Assimilation Rate (NAR) and yield of corn under drought stress.

\section{MATERIALS AND METHODS}

The experiment was conducted in 2008 at experimental farm of Arsanjan Islamic Azad University $\left(53^{\circ} 16^{\prime} \mathrm{N}, 50^{\circ} 29^{\prime} \mathrm{E}\right)$. The soil texture was sandy loam and result soil analysis is shown in Table 1.

Treatment consisted of two level drought stress: one without stress ( 8 days period of irrigation) and the other drought stress ( 12 days period of irrigation) that used after pollination and there were four fertilizer treatments: (1) no fertilizer (control). (2) Organic fertilizer (4 Lit.ha $^{-1}$ from source of KadostimPhosPhotern-Aminolephorte and Hiomiphorte) which applied in vegetative, flowering and milk stages. (3) Chemical fertilizer (300 kg.ha ${ }^{-1}$ from source of Urea fertilizer) which applied pre sowing, 6th leaf appearance and pre flowering. (4) Utilization of both biological and chemical fertilizers. The experiment was conducted in a split plot with completely randomized block design using four replications. The test crop was corn (Zea mays L. var. Maxima). Each experimental plot was $16 \mathrm{~m}^{2}$ including five planting row with $3 \mathrm{~m}$ length and with distancing $0.6 \mathrm{~m}$ and each plant was $20 \mathrm{~cm}$ a per. Plants were harvested at maturity for yield and yield components and leaf area index and dry matter were measured at both of vegetative and reproduction stages each 15 days for calculating Crop Growth Rate (CGR), Net Assimilation Rate (NAR) and Leaf Area Index (LAI):

$\mathrm{LAI}=\mathrm{LA} / \mathrm{SA}$

$\mathrm{CGR}=\mathrm{W}_{2}-\mathrm{W}_{1} / \mathrm{t}_{2}-\mathrm{t}_{1}$

$\mathrm{NAR}=\mathrm{CGR} / \mathrm{LAI}$

In above abbreviations:

LA $=$ Leaf Area

$\mathrm{SA}=$ Ground area that occupied a plant

$\mathrm{W}=$ Dry matter

$\mathrm{t}=$ Day after planting

Data were subjected to Analysis Of Variance (ANOVA) and the treatment means were compared using Duncan multiple range test.

Table 1: Soil properties of experimental field

\begin{tabular}{lllllll}
\hline $\begin{array}{l}\text { Deep of } \\
\text { soil }(\mathrm{cm})\end{array}$ & $\begin{array}{l}\text { EC } \\
\left(\mathrm{ds} . \mathrm{m}^{-1}\right)\end{array}$ & $\mathrm{PH}$ & $\begin{array}{l}\text { Organic } \\
\text { matter }(\%)\end{array}$ & $\mathrm{N}(\mathrm{ppm})$ & $\mathrm{P}(\mathrm{ppm})$ & $\mathrm{K}(\mathrm{ppm})$ \\
\hline $0-30$ & 0.58 & 7.8 & 1.00 & 320 & 5.7 & 150.0 \\
$30-60$ & 0.76 & 7.6 & 0.75 & 230 & 4.6 & 135.5 \\
\hline
\end{tabular}

\section{RESULTS}

Grain yield: The result showed that, the highest grain yield was in conditional application integrated treatment $300 \mathrm{~kg} \cdot \mathrm{ha}^{-1}$ Urea fertilizer and $4 \mathrm{~L}^{-\mathrm{ha}^{-1}}$ biological fertilizer (12.5 ton.ha ${ }^{-1}$ ) that compared to control treatment showed increase $257 \%$. Application integrated chemical fertilizer with biological fertilizer caused to be produce highest yield compared with application chemical and biological treatment alone (Amujoyegbe et al., 2007; Rizwan et al., 2008). In this treatment, drought stress (12 days period of irrigation) decreased $8.9 \%$ in yield (Table 2). Drought stress is a major abiotic constraint responsible for heavy production losses (Khan et al., 2007). Application $300 \mathrm{~kg} \cdot \mathrm{ha}^{-1}$ urea fertilizer, obtained highest yield (11.36 ton.ha $\mathrm{a}^{-1}$ ) compared with control treatment showed increase $110 \%$ in yield and this treatment drought stress decrease $13.7 \%$ in yield but application 4 Lit.ha $^{-1}$ biological fertilizer compared with control treatment increased $43.5 \%$ (Table 2). Organic and inorganic fertilizers applied to the soil affect the plant physiological processes, which serve as important instruments in yield development.

Kernel number per ear: The highest kernel number per ear, obtained at integrated treatment $300 \mathrm{~kg} \cdot \mathrm{ha}^{-1}$ urea fertilizer and $4 \mathrm{~L}^{2} \mathrm{ha}^{-1}$ (550 number) in this treatment drought stress decreased $1.9 \%$ in kernel number per ear (Table 3). Although application one of the chemical and biological fertilizer treatments can not produce kernel number per ear more than integrated treatment. In $300 \mathrm{~kg} \cdot \mathrm{ha}^{-1}$ urea fertilizer treatment, kernel number per ear was (520 number) and in biological fertilizer treatment was (477 number) (Table 3).

Table 2: Interaction between chemical and biological fertilizer in 8 and 12 days period of irrigation on the yield (ton.ha ${ }^{-1}$ ) in corn (var. Maxima)

\begin{tabular}{|c|c|c|c|c|}
\hline Treatment & Control & $\begin{array}{l}\text { Biological } \\
\text { fertilizer }\end{array}$ & $\begin{array}{l}\text { Chemical } \\
\text { fertilizer }\end{array}$ & $\begin{array}{l}\text { Utilization of } \\
\text { both bio. and } \\
\text { chem. fertilizer }\end{array}$ \\
\hline $\begin{array}{l}8 \text { days period } \\
\text { of irrigation }\end{array}$ & $3.5 \mathrm{~d}$ & $7.4 \mathrm{c}$ & $11.36 \mathrm{~b}$ & $12.5 \mathrm{a}$ \\
\hline $\begin{array}{l}12 \text { days period } \\
\text { of irrigation } \\
\text { (drought stress) }\end{array}$ & $2.9 \mathrm{~d}$ & $6.9 \mathrm{c}$ & $9.4 \mathrm{~b}$ & $11.4 \mathrm{a}$ \\
\hline
\end{tabular}

Table 3: Interaction between chemical and biological fertilizer in 8 and 12 days period of irrigation on the kernel number per ear in corn (var. Maxima)

\begin{tabular}{|c|c|c|c|c|}
\hline Treatment & Control & $\begin{array}{l}\text { Biological } \\
\text { fertilizer }\end{array}$ & $\begin{array}{l}\text { Chemical } \\
\text { fertilizer }\end{array}$ & $\begin{array}{l}\text { Utilization of } \\
\text { both bio. and } \\
\text { chem. fertilizer }\end{array}$ \\
\hline $\begin{array}{l}8 \text { days period } \\
\text { ff irrigation }\end{array}$ & $249 d$ & $477 \mathrm{c}$ & $520 \mathrm{~b}$ & $550 \mathrm{~b}$ \\
\hline $\begin{array}{l}12 \text { days period } \\
\text { ff irrigation } \\
\text { (drought stress) }\end{array}$ & $219 d$ & $379 c$ & $495 b$ & $546 a$ \\
\hline
\end{tabular}


Am. J. Agri. \& Biol. Sci., 5 (2): 189-193, 2010

Table 4: Interaction between chemical and biological fertilizer in 8 and 12 days period of irrigation on the 1000 kernel weight (g) in corn (var. Maxima)

\begin{tabular}{lllll}
\hline & & & & Utilization of \\
Treatment & Control & $\begin{array}{l}\text { Biological } \\
\text { fertilizer }\end{array}$ & $\begin{array}{l}\text { Chemical } \\
\text { fertilizer }\end{array}$ & $\begin{array}{l}\text { both bio. and } \\
\text { chem. fertilizer }\end{array}$ \\
\hline $\begin{array}{l}8 \text { days period } \\
\text { of irrigation }\end{array}$ & $243.0 \mathrm{~b}$ & $200.0 \mathrm{c}$ & $286 \mathrm{a}$ & $300 \mathrm{a}$ \\
$\begin{array}{l}12 \text { days period } \\
\text { of irrigation } \\
\text { (drought stress) }\end{array}$ & $237.5 \mathrm{c}$ & $187.5 \mathrm{~d}$ & $275 \mathrm{~b}$ & $287 \mathrm{a}$ \\
\hline
\end{tabular}

Table 5: Interaction between chemical and biological fertilizer in 8 and 12 days period of irrigation on the leaf area index in corn (var. Maxima)

\begin{tabular}{|c|c|c|c|c|}
\hline Treatment & Control & $\begin{array}{l}\text { Biological } \\
\text { fertilizer }\end{array}$ & $\begin{array}{l}\text { Chemical } \\
\text { fertilizer }\end{array}$ & $\begin{array}{l}\text { Utilization of } \\
\text { both bio. and } \\
\text { chem. fertilizer }\end{array}$ \\
\hline $\begin{array}{l}8 \text { days period of } \\
\text { irrigation }\end{array}$ & $2.4 \mathrm{~d}$ & $3.3 \mathrm{c}$ & $4.3 b$ & $5.10 \mathrm{a}$ \\
\hline $\begin{array}{l}12 \text { days period of } \\
\text { irrigation } \\
\text { (drought stress) }\end{array}$ & $2.2 \mathrm{~d}$ & $3.1 \mathrm{c}$ & $3.5 b$ & $4.76 \mathrm{a}$ \\
\hline
\end{tabular}

1000 kernel weight: The highest 1000 kernel weight was in integrated chemical and biological treatment (300 g) but in 8 days period of irrigation there was no significant difference between integrated treatment and chemical treatment (286 g) (Table 4). Ibeawuchi and Onweremalu (2007) in an experiment showed that, at first of all the highest 1000 kernel weight was in integrated fertilizer treatments and the following was in chemical fertilizer (8). The application of $300 \mathrm{~kg} \cdot \mathrm{ha}^{-1}$ urea fertilizer, produced 1000 kernel weight with (286 g) compared with control treatment increased $27.7 \%$ on that but in this treatment drought stress decreased $3.1 \%$ 1000 kernel weight (Table 4).

Leaf Area Index (LAI): Leaf area index with the use of $300 \mathrm{~kg} \cdot \mathrm{ha}^{-1}$ urea fertilizer in 8 days period of irrigation was (4.3) in which drought stress in this treatment decreased $22.9 \%$ in LAI (Table 5). Application biological fertilizer treatment alone in 8 and 12 days period of irrigation observed that drought stress in this treatment there was no significant difference on the LAI, this result showed that biological fertilizer to obtain relative resistance opposes the drought stress (Table 5). The highest LAI was in integrated treatment in 8 days period of irrigation (5.1) and drought stress in this treatment decreased $11 \%$ in LAI. In this study there was a significant correlation between LAI and yield $(r=0.91 * *)$ furthermore the regression between LAI and yield $\left(y=0.7967 x^{2}-2.884 x+7.3\right)$ showed that increase in LAI, will result to yield increase (Fig. 1).

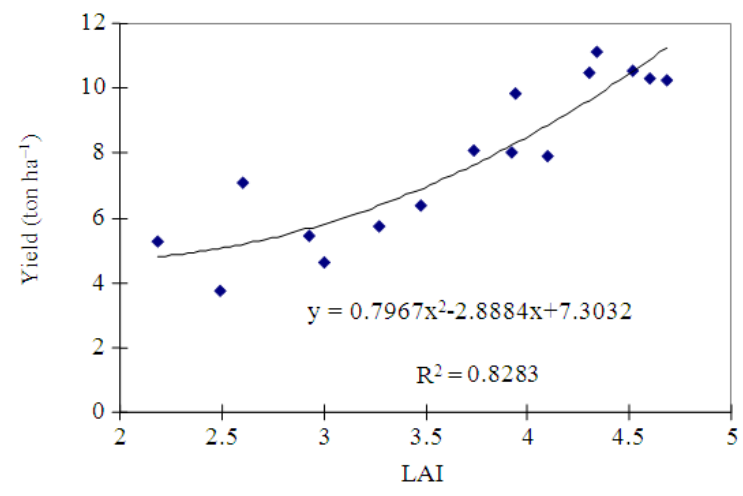

Fig. 1: Relationship between leaf area index and grain yield in corn (var. Maxima) in two difference irrigation

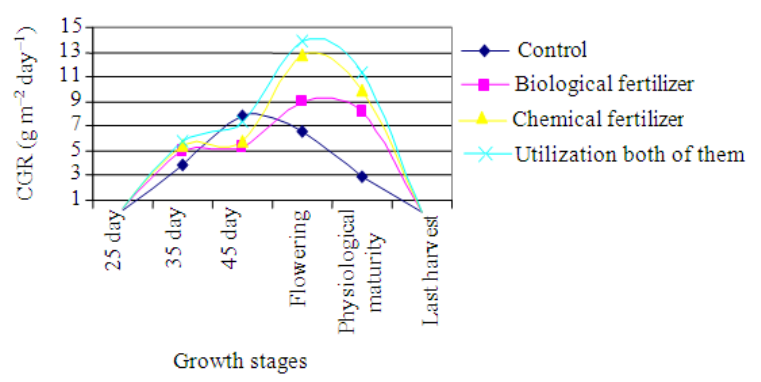

Fig. 2: Crop growth rate in four fertilizer treatment in during period of growth

Crop Growth Rate (CGR): Crop growth rate in integrated $300 \mathrm{~kg} \cdot \mathrm{ha}^{-1}$ urea and 4 L.ha ${ }^{-1}$ biological fertilizer (14.2 $\mathrm{g} \mathrm{m}^{-2}$ day $^{-1}$ ) during the experiment was increased compared with other treatment (Fig. 2). Probably in this experiment some of the many differences at crop growth rate is related to leaf area index, for this reason that crop growth rate changes is depended to two parameters: Namely leaf area index and net assimilation rate. This result was verified by Brogeham (2000) in Newzealand (3). Application $300 \mathrm{~kg} \cdot \mathrm{ha}^{-1}$ urea fertilizer sole produced CGR (12.72 $\mathrm{g} \mathrm{m}^{-2} \mathrm{day}^{-1}$ ) (Fig. 3) and application 4 L.ha ${ }^{-1}$ biological fertilizer produced CGR (9.1 g m g $^{-2} \mathrm{day}^{-1}$ ) (Fig. 4). Drought stress in tassel stage in chemical fertilizer treatment caused more decrease CGR compared with biological fertilizer (Fig. 3 and 4).

Net Assimilation Rate (NAR): The result of this experiment showed that seasonal pattern changes of net assimilation rate in all of fertilizer treatments, had trend decrease. This further showed that the age increase of plant caused decrease in NAR decreased (Fig. 5). 
Am. J. Agri. \& Biol. Sci., 5 (2): 189-193, 2010

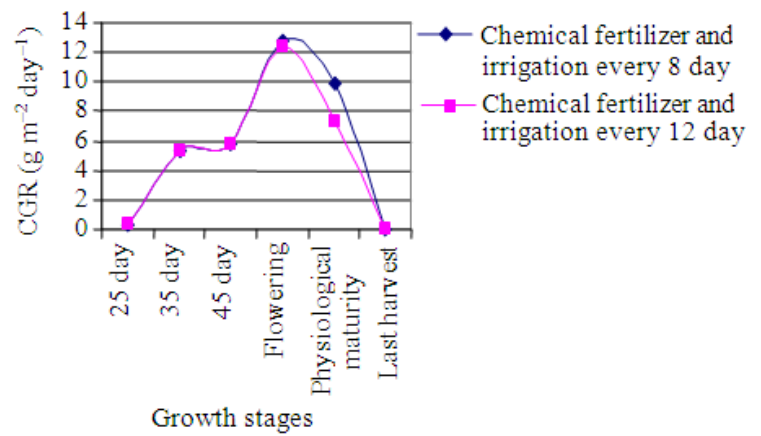

Fig. 3: Crop growth rate in chemical fertilizer in two difference irrigation

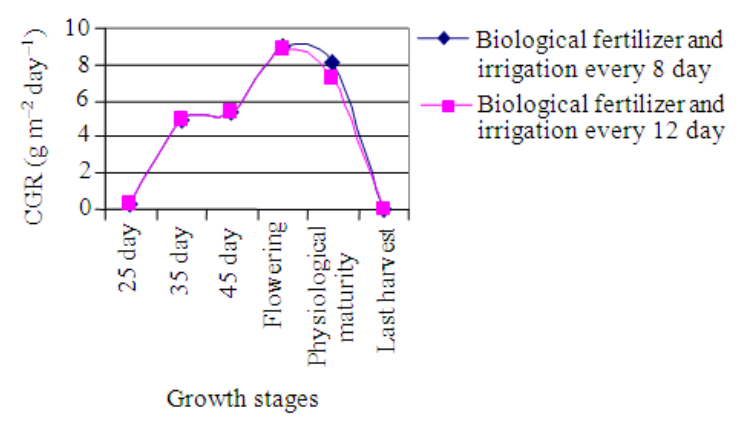

Fig. 4: Crop growth rate in biological fertilizer in two difference irrigation

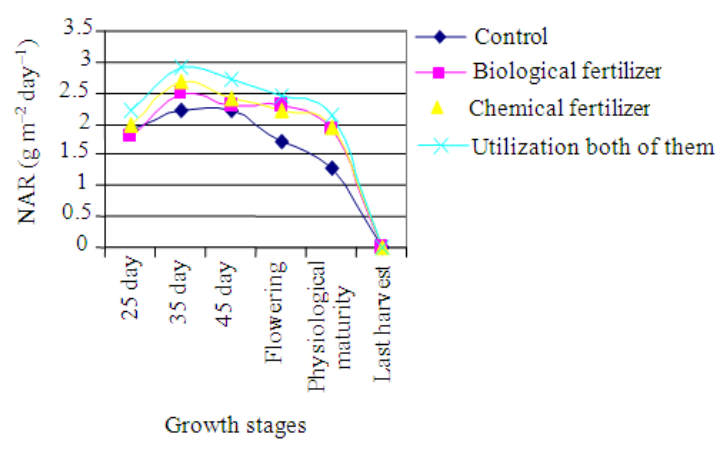

Fig. 5: Net assimilation rate in four fertilizer treatment in during period of growth

Although NAR in all fertilizer treatments decreased but NAR pattern changes have little difference. In integrated $300 \mathrm{~kg} \cdot \mathrm{ha}^{-1}$ urea fertilizer and $4 \mathrm{~L}^{\mathrm{ha}}{ }^{-1}$ biological fertilizer $\left(2.9 \mathrm{~g} \mathrm{~m}_{\mathrm{LA}}{ }^{-2} \mathrm{day}^{-1}\right)$ had highest NAR in 8 and 12 days period of irrigation (Fig. 6). The effect of drought stress on decrease NAR in use of chemical fertilizer was more than biological fertilizer (Fig. 7 and 8). Balak (1993) and Williams (1965) showed that NAR would decrease with increase LAI (2). This trend decrease will continue from the beginning till the end of growth season.

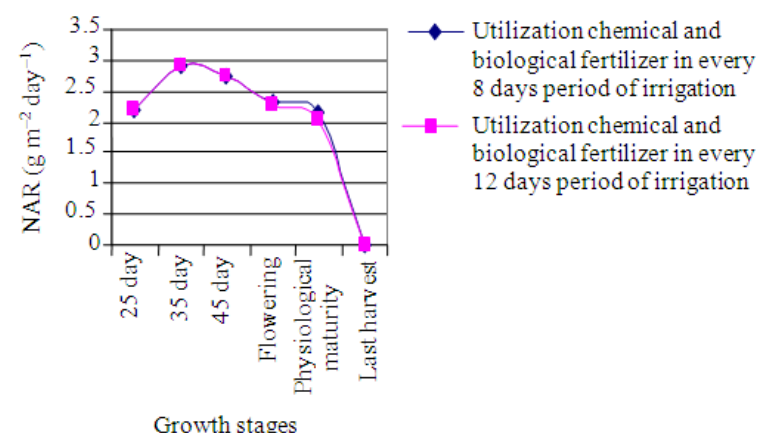

Fig. 6: Net assimilation rate in utilization chemical and biological fertilizer in two difference irrigation

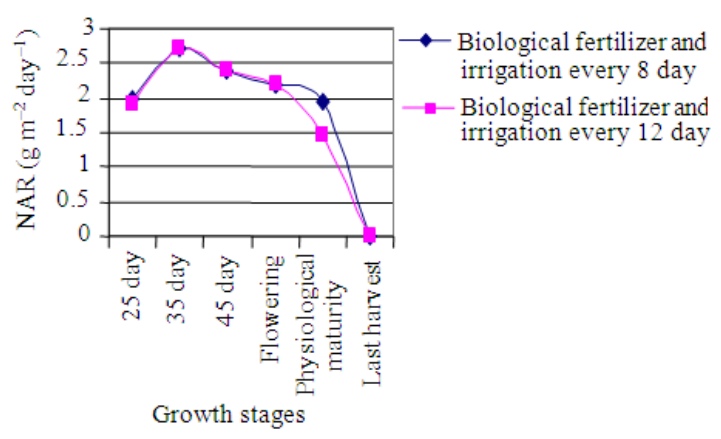

Fig. 7: Net assimilation rate in biological fertilizer in two difference irrigation

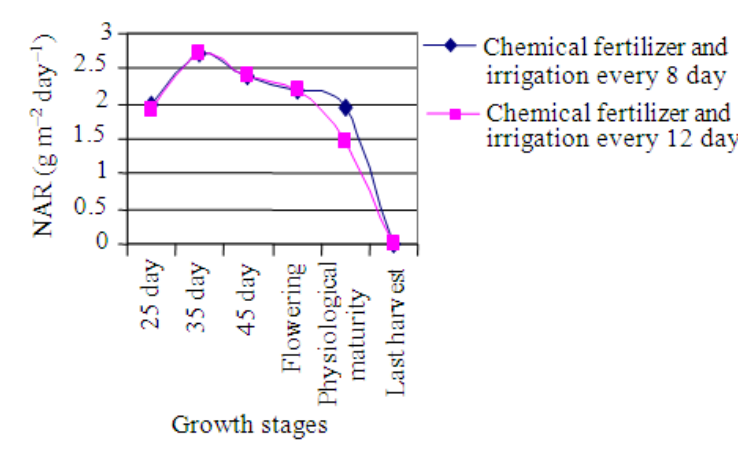

Fig. 8: Net assimilation rate in chemical fertilizer in two difference irrigation

\section{DISSCUSION}

Present results showed that integrated application of fertilizers (Biological and Chemical fertilizers) increase yield and its component. Amujoyegbe et al. (2007) and Rizwan et al. (2008) reported that application integrated chemical fertilizer with biological fertilizer caused to be produce highest yield compared with application chemical and biological treatment alone $(1,13)$. Organic 
and inorganic fertilizers applied to the soil affect the plant physiological processes, which serve as important instruments in yield development. Ibeawuchi and Onweremalu (2007) in an experiment showed that, at frist of all the highest 1000 kernel weight was in integrated fertilizer treatments and the following was in chemical fertilizer (8). El-Karmany (2001) showed that integrated chemical and biological fertilizer obtained highest kernel number per ear compared with sole application of them (4).

Result of the current study indicate that, drought stress caused decreases in yield and its component and LAI, CGR and NAR but effect of drought stress in integrated treatment was less than one of the fertilizer treatment sole also. Drought stress is a major abiotic constraint responsible for heavy production losses (Khan et al., 2007).

Probably in this experiment some of the many differences at crop growth rate is related to leaf area index, for this reason that crop growth rate changes is depended to two parameters: namely leaf area index and net assimilation rate. This result was verified by Brongeham (2000) in Newzeland also Balak (1993) and Williams (1965) showed that NAR would decrease with increase LAI $(2,3,16)$.

\section{CONCLUSION}

Long-term balanced fertilization with nutrients is the basic and main pathway to maintain high soil productivity in the farmland ecosystems. A combination of chemical fertilizer and biological fertilizer has given the highest crop yield in this study. Also chemical fertilizer combined with biological fertilizer was benefit to the environment because with decrease use of chemical fertilizer and use of inputs organic can move to side sustainable agriculture, increase efficiency and decrease use of water.

\section{REFERENCES}

Amujoyegbe, B.Y., J.T. Opbode and A. Olayinka, 2007. Effect of organic and inorganic fertilizer on yield and chlorophyll content of Zea mays and Sorghum bicolor. Dept. Plant Sci., 46:186-174.

Balak, D.G.R., 1993. A growth analysis comparison of corn growth in conventional and equidistant plant spacing. Crop Sci., 24: 1184-1191.

Brogeham, B., 2000. A growth stage key for rape. Can. J. Plant Sci., 53: 473-482.

El-Karmany, M., 2001. Effect of organic manure and slow-release $n$-fertilizer on the productivity of wheat in sandy soil. Acta Agronom. Hungarica, 49: 379-385.
Fisher, K.S. and G.L. Wilson, 1975. Effect of fertilizer on growth and yield in Sorghum bicolor. Aust. J. Agric. Res., 26: 31-41.

Follet, R.H., Murphy, L.S. and R.L. Donalua, 1981. Soil-fertilizer-plant relationship. Fertilizer Soil Amendment. 16: 478-481

Higa, T., 1994. The Complete Data of Em Encyclopedia. 2nd Edn., Sogo-Unicom in Japanese, Tokyo, pp: 385-388.

Ibeawuchi, I. and E. Onweremalu, 2007. Effects of poultry manure on green and waterleaf on degraded ultisol of Owerri South Eastern Nigeria. J. Anim. Veterin. Adv., 1: 6-53.

Khan, H., Link, T. J. Hocking and F. L. Stoddard, 2007. Evaluation of physiological traits for improving drought tolerance in faba bean (Vicia Faba L.). Plant Soil. 292: 205-217.

Kumar, M.V.N. and S.S. Kumar, 2004. Studies on character association and path efficient for grain and oil content in maize. Ann. Agric., 73-78.

Li, W.J. and Y.Z. Ni, 1996. Researches on application of microbial inoculant in crop production. In: Researches and application of En technology, Agriculture University Press, Beijing, China, pp: 42-84.

Oad, F.C.V., A. Buriro and S.K. Agla, 2004. Effect of organic and inorganic fertilizer application maize fodder production. Asian J. Plant Sci., 3: 375-377.

Rizwan, A., M. Arshad, A. Khalid and A. Zahir, 2008. Effectiveness of organic bio-fertilizer supplemented with chemical fertilizer for improving soil water retention. Aggregate stability, growth and nutrient uptake of maize. J. Sustain. Agric., 34: 57-77.

Sivasubramaniawn, K., 1992. Chlorophyll stability index: methods for determining drought Hardness of Acacia species. Nitrogen Fixing Tree Research Reports. 10: 111-112.

Taiz, L. and E. Zeiger, 2002 Plant Physiology. 3rd Edn., Sinauer Associates Publisher, ISBN: 0878938230, pp: 690.

Williams, W.A., 1965. Vegetative growth of corn as affected by population density on yield and component yield of growth, net assimilation rate and leaf area index. Crop Sci., 5: 215-219.

Zeid, I.M., 2008. Effect of Arginine and urea on polyamines content and growth of bean under salinity stress. Acta Physiologiea Plantarum, 10: 201-209. 